\title{
Phytomedicinal Knowledge and "Official" Sources in Tatev (Armenia)
}

\author{
Roman Hovsepyan ${ }^{1 *}$, Nina Stepanyan-Gandilyan ${ }^{2}$, and Christian Stollberg ${ }^{3}$ \\ ${ }^{1}$ Institute of Archaeology and Ethnography, Yerevan, Armenia. ${ }^{2}$ Institute of Botany, Yerevan, Armenia. ${ }^{3}$ Hochschule Wismar- \\ University of Applied Sciences, Technology, Business and Design, Malchow/ Insel Poel, Germany. \\ *roman.hovsepyan@gmail.com
}

\begin{abstract}
Ethnographic investigations in the villages of the Tatev community in southern Armenia reveal the positive attitude of the local community toward "official" sources (e.g., printed books, administrative officials, and people of higher education) on herbal medicine and the belittling of their own traditional ethnobotanical knowledge. Although this may be a global phenomenon, we observe and discuss particular reasons specific to the post-Soviet context as conditioned by politics and propaganda. Nowadays, the local population gather and use a minimum of forty wild plants (ethnotaxa) mostly for nutritional, medicinal, and aromatic (tea and flavoring) purposes. Biological species of the traditionally used medicinal plants of the Tatev community were identified, and preparation methods and purposes of the herbal remedies were recorded. The most frequently and traditionally used medicinal plants of the Tatev community belong to these genera: Mentha, Thymus, Ziziphora, Hypericum, Knautia, Arctium, Plantago, Tanacetum, Rosa, and Sambucus.
\end{abstract}

Received February 14, 2018

OPENӘACCESS

Accepted April 8, 2019

DOI 10.14237/ebl.10.1.2019.1266

Published June 2, 2019

Keywords Folk medicine, Books, Traditions, Epistemology, Herbal market

Copyright (c) 2019 by the author(s) licensee Society of Ethnobiology. This is an open-access article distributed under the terms of the Creative Commons Attribution-NonCommercial 4.0 International Public License (https://creativecommons.org/licenses/by-nc/4.0), which permits non-commercial use, distribution, and reproduction in any medium, provided the original author and source are credited.

\section{Introduction}

The Attitude towards Traditional Knowledge and "Official" Sources

As with the rest of the world, traditional ethnomedicinal knowledge is at risk in Armenia and is gradually fading away due to migration, urbanization, and competition with modern medicine and pharmaceuticals. Additionally, government propaganda in Armenia and other Soviet countries emphasized the importance of official education and science and belittled folk knowledge (e.g., Allayarov 1993; Boldyrev 2017; Mikhlin and Kiryak 1985; Mirakyan 1930) ${ }^{1}$. The belief in the efficacy of traditional folk medicine and its various applications was considered backward (e.g., Boldyrev 2017; Khudabashian 1917a, 1917b; Malkhasyan 1929; Ohanyan 1917; etc.), and folk doctors (bakim —Arabic word for doctor) were marginalized by mainstream society (e.g., Eaton 2004; Knaus, Petroff 1982; Phillips 2004; Q.O. 1917). As a result, many peopleespecially the younger generations-tried to avoid folk medicine during the Soviet period (e.g., Ayvazyan 1927; Boldyrev 2017; Harutyunyan 1927; Malkhasyan
1929; etc.). Through inertia, this same generation continues to avoid folk medicine in the present. Many folk medicinal practices were neglected and discontinued, and traditional knowledge was forgotten. "Our grandparents knew more; now nobody cares about traditions," one elderly man from Tatev lamented. Traditional folk knowledge (e.g., medicinal, agricultural, nutritional, architectural, etc.) was replaced both in an overtly imposed way through knowledge retrieved from books and official instructions from the government (e.g., Bashkuev 2017) and in less apparent ways through printed propaganda (e.g., Boldyrev 2017; Mikhlin and Kiryak 1985). Sometimes, when it was impossible to negate the usefulness of medicinal plants and folk medicine in general, this knowledge was "officialized" and returned to people through propaganda or educational materials as part of Soviet knowledge concerning medicine, production, and the household (e.g., Eaton 2004; Knaus and Petroff 1982; Medynskiy 1952: 96, 100, 109). Mass media, especially printed sources including books, journals, and documents, were among the earliest and longest-lasting sources of 


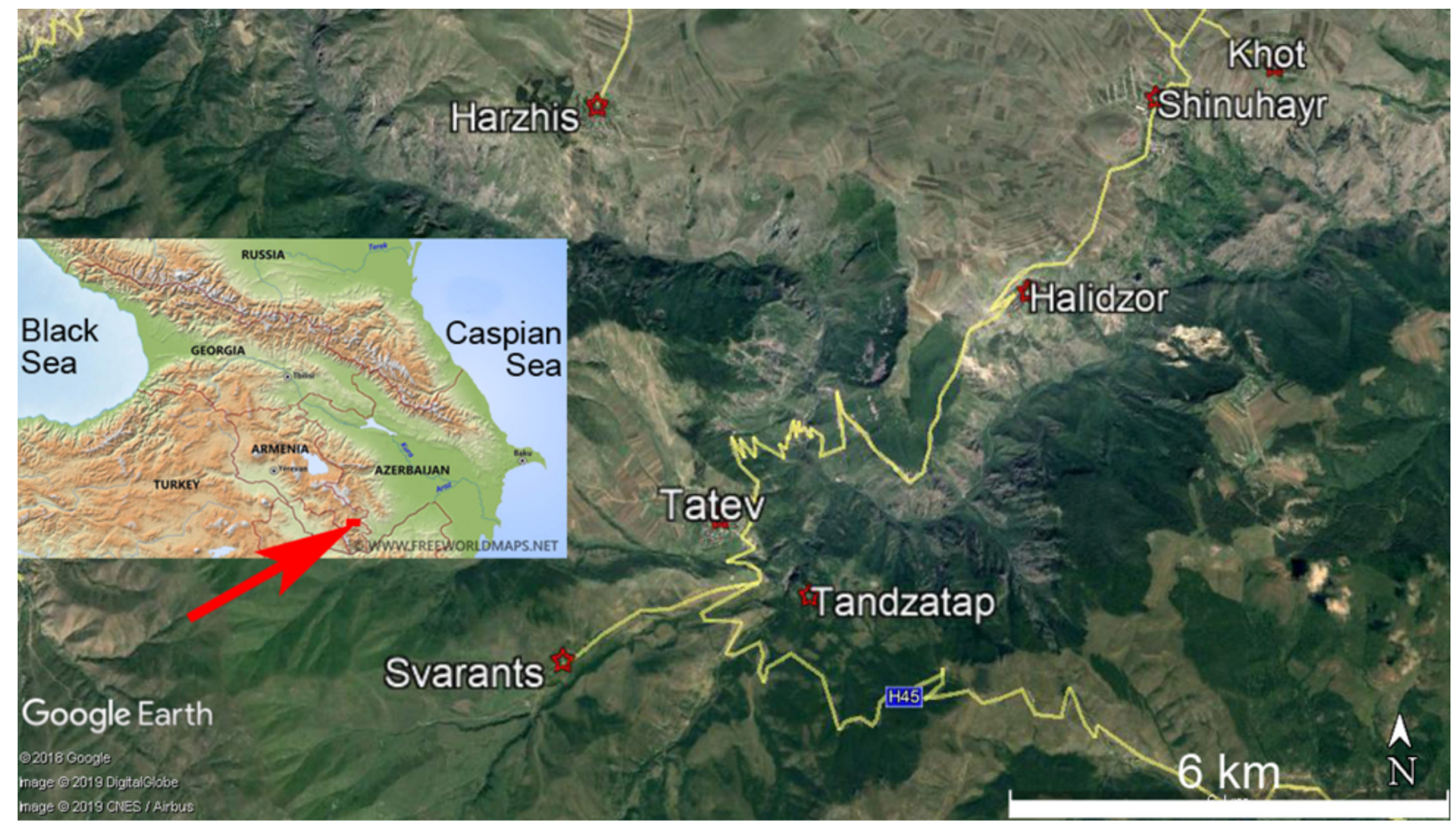

Figure 1 Map of the studied region: Tatev and neighbouring villages, Syunik, Armenia. The Tatev community: Tatev (N39 ${ }^{\circ}$ 23'8.79", E46¹4'29.34"; 1500-1670 m a.s.l.; population ${ }^{2}-1042$ ), Tandzatap (N39²2'27.55", E46¹5'27.78"; $1350-1400 \mathrm{~m}$ a.s.l.; population ${ }^{2}-103$ ), Svarants (N39 $21^{\prime} 53.63^{\prime \prime}, \mathrm{E} 46^{\circ} 13^{\prime} 3.52^{\prime \prime}$; $1700-1825 \mathrm{~m}$ a.s.l.; population ${ }^{2}-283$ ), Halidzor (N39 ${ }^{\circ}$ 24'42.03", E46 $17^{\prime} 31.46^{\prime \prime} ; 1320-1400$ m a.s.l.; population ${ }^{2}-602$ ), Shinuhayr (N39²6'3.13", E46¹8'55.93"; $1470-1550 \mathrm{~m}$

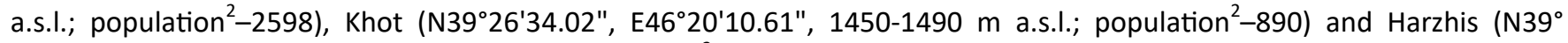
26'6.40", E46 $13^{\prime} 23.63^{\prime \prime} ; 1700-1750$ m a.s.l.; population ${ }^{2}-831$ ).

this propaganda. Because the government controlled all printed media during the Soviet period (e.g., Blium and Farina 1998; Markwick 2013; Plamper 2001; Venclov 1978; etc.), people began to consider all printed sources to be official. This strengthened the respect of the population toward printed sources.

In this article we attempt to introduce the attitude of post-Soviet Armenian society toward the traditional knowledge of folk medicine, focusing on a case study of the community of Tatev (Figure 1), and address a similar phenomenon in trader-buyer relations in the local market. We do not claim that the special attitude of Armenians and others from the Soviet Union concerning printed sources is unique. It is a common phenomenon and possibly related to a culture of respecting education. We suggest that Soviet propaganda contributed to the belittling of traditional knowledge and strengthening the respect the population holds regarding printed sources.
The Market at the Tatev Monastery

We chose the community of Tatev for its large and diverse market of herbs. After the 2010 construction of the Wings of Tatev, an aerial tramway, ${ }^{3}$ a street market was established next to the gates of the medieval monastery of Tatev, built in the $9^{\text {th }}$ century $\mathrm{AD}$ (Figures 2 and 3), in response to the rapid increase of tourism in the area. The market extends along the path leading to the medieval monastery and the vegetable oil-pressing factory. The main goods traded in this market are medicinal and aromatic plants, folk remedies, homemade products including various sweets, jams, drinks, spirits, dry yogurt, kinds of honey, handicrafts, and sometimes other village products like grains and fruits (Figure 3). Our investigation of the market is focused on discovering both traditional and recently learned ethnomedicinal knowledge. The market survives exclusively on trade with tourists, growing and shrinking depending on the season and flow of visitors, and no locals were 


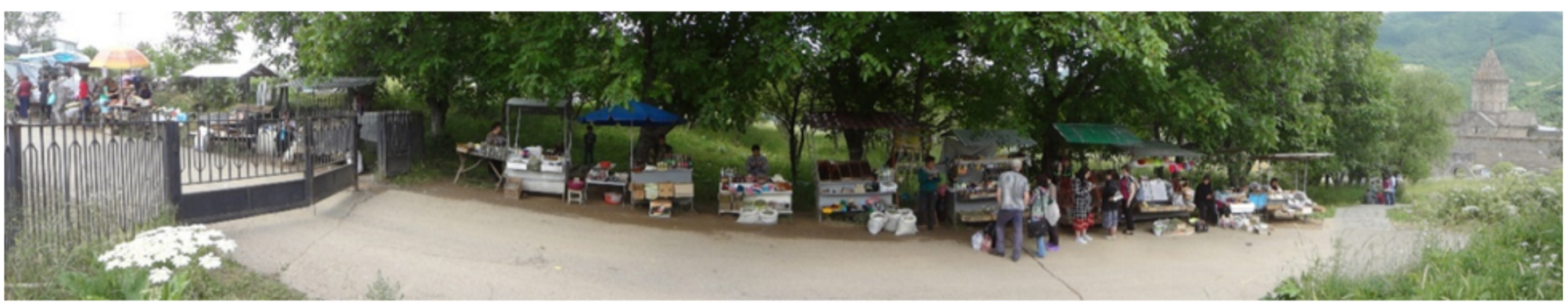

Figure $\mathbf{2}$ The market at the Tatev Monastery (June 2017).

observed buying any products there. Interviews revealed that a small number of locals, including an elderly woman selling wild herbs and garden products (Figures 3 and 4), were primarily responsible for initiating the market and that only later did it evolve into a tourist attraction. Most of the vendors ${ }^{4}$ are locals from Tatev and the surrounding villages. A networking system has formed among sellers so that the assortment of goods is similar, prices are agreed upon, and sellers support each other when necessary. Sellers have at least a basic knowledge of the Armenian, Russian, and sometimes even English names of the plants they sell as well as each plant's use and different preparations for remedies and prescriptions.

\section{Methods}

The study area is situated in the south of the Republic of Armenia, in the region of Syunik or Zangezour, in the basin of the Vorotan River (a tributary of the Araxes River). We carried out our fieldwork in seven villages belonging to the Tatev community (total population $n=6107$, practically all are Armenians ${ }^{2}$ ) in the Syunik region in Armenia during June of 2017, and April and June of 2018 (Figure 1).

During our research we adhered to the Code of Ethics of the International Society of Ethnobiology (2006). We began our interactions with research participants by introducing ourselves, our work, and our plans. Then, if we obtained their oral consent, we used semi-structured interviews and direct observations. We began our interviews in the Tatev market, because it has the highest apparent concentration of medicinal plants and all the traders presumably possess knowledge about their use. There were 14 boutiques and a corresponding number of traders in the market. All the traders were women of Armenian nationality from the Tatev village, most of them 45-70 years old (two were younger, around 35, and one was older, over 80 ). These women all held secondary school education except the eldest, who held an elementary school education. All the traders of the Tatev herbal market were interviewed regarding the plants they traded, their uses, preparation methods of the herbal remedies, gathering places, how they or their suppliers gather herbs, and the seasonality of the plants' harvest. We also inquired about the origin of their knowledge, trading, and the history of the market, although only relevant information from the interviews is presented in this article.

Along with the process of conducting interviews, we collected samples of the medicinal plants sold in the market for further identification. Then, we conducted semi-structured interviews with elderly and middle-aged people in Tatev and in the neighboring villages. The majority of our research participants were over 40 years old. Since it was suggested to us that women were the main bearers of traditional ethnobotanical knowledge in Tatev, elderly women comprise a large portion of our interviews. In general, the occupations of the locals are centered on agriculture and farming. Interviews occurred primarily in the yards or in the houses of the research participants and, in several cases, in the fields from which they gather plants (Figure 5). The research participants were thus often able to show us particular plants they were discussing as the plants were dried/ conserved in the house or still growing in their natural habitat.

In total we interviewed 76 locals, all ethnic Armenians, including the traders from the market. The demographics of the interviewees are as follows:

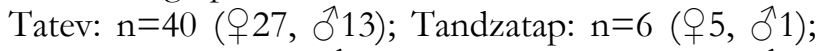

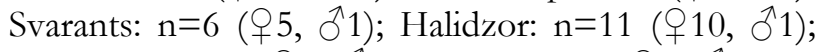

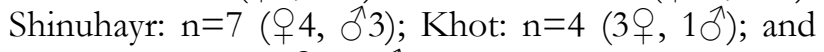
Harzhis: $\mathrm{n}=2$ (1, 10$)$. After fewer than 10 interviews, we noticed that information regarding the assemblage of locally known medicinal plants, the purposes of their use, remedy preparation and utilization options and, in general, ethnomedicinal knowledge was mostly similar from one research participant to another, and from village to village. 

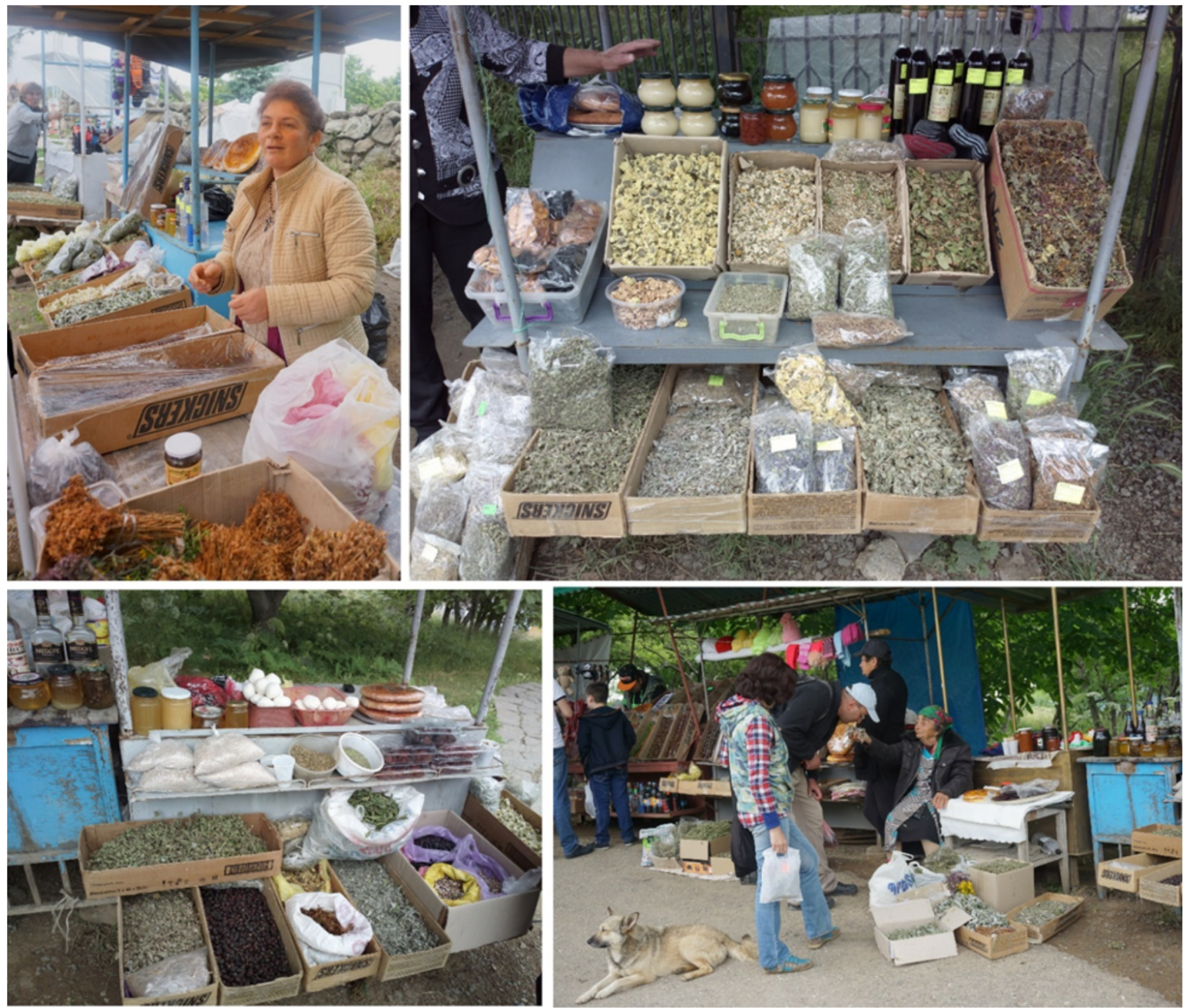

Figure 3 The artisan market along the road to the Tatev Monastery (June 2017). Primarily medicinal and aromatic plants and homemade products (jams, wines, vodkas, honeys, sweets, etc.) are traded here.

We consulted the Flora of Armenia as the principal reference to identify the collected herbarium material (Takhtajyan 1954-2010). The selected herbarium material was registered and stored in the Herbarium of the Institute of Botany in Yerevan [ERE].

\section{Results}

We documented around 40 ethnotaxa of wild plants that were traditionally used by the local population. These plants include around 80 biological species primarily from the following genera: Allium, Amaranthus, Anthemis, Arctium, Asparagus, Berberis,
Bryonia, Carum, Celtis, Cephalaria, Cerasus, Chenopodium, Cherophyllum, Crataegus, Echinops, Falcaria, Heracleum, Hypericum, Knautia, Laser, Latbyrus, Malus, Malva, Mentha, Papaver, Plantago, Polygonatum, Portulaca, Primula, Prunus, Pyrus, Rosa, Rumex, Salvia, Sambucus, Satureja, Tanacetum, Thalictrum, Thymus, Trifolium, Urtica, Vicia, and Ziriphora, as well as species of the Apiaceae family. We assigned the plants to three main categories to distinguish among their primary uses: nutritional, aromatic (flavoring or tea), and medicinal. However, in most cases, there is no strict ascription to a certain group and the locals use the same plant for 

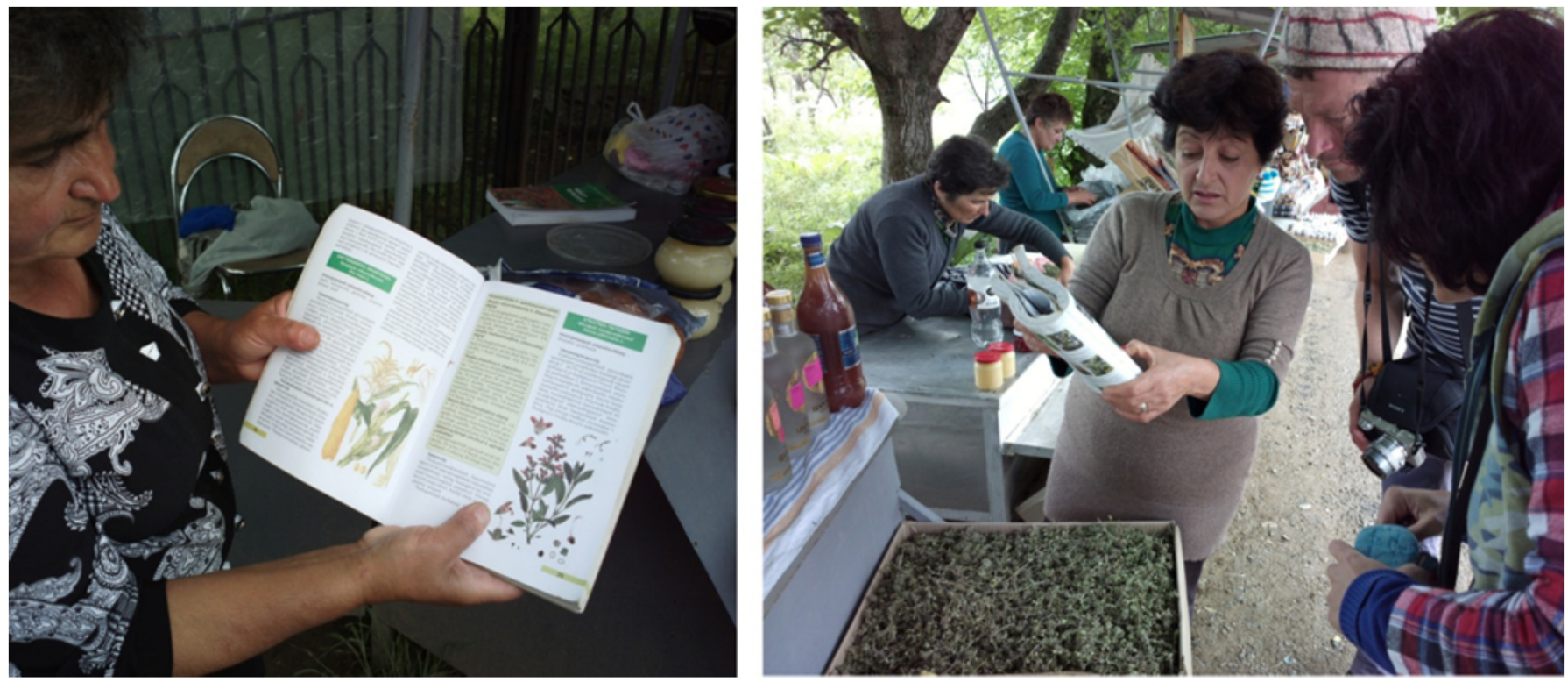

Figure 4 Traders from the artisan market at the gates of the Tatev Monastery presenting information about the plants they trade (June 2017).

several purposes. Often those plants which are primarily used for tea (aromatic) or food are also used for prophylactic healing and preventive purposes. In general, the locals consider all wild edible plants as useful and possessing healing features. For example, one man from Tatev remarked, "We eat it [the plant] and it is also healthy". The locals tend to believe that all edible plants have a positive effect, especially on the digestive system. Usually they do not specify this effect, noting, "it is good for digestion/belly/ stomach/intestines." When we asked them to be more specific, they said that, "it heals the stomach and intestines," specifically helping to heal gastric and duodenal ulcers or relieving the pain caused by ulcers, clearing intestines, and stopping diarrhea.

In this article, we present and discuss only the medicinal and aromatic plants. The locals of Tatev and neighboring villages know and use 19 ethnotaxa of medicinal and aromatic plants, although the biological taxonomical composition of these plants is more diverse, representing 31 species. In other words, locals use the same name to refer to several plants that usually have a similar habitus (Table 1). It is possible that the number of biological species might be higher as locals tend to identify the plants mostly at the biological genus level.

Members of the Tatev community often use the entire aerial (aboveground) portion of the medicinal and aromatic plants, but preferred aerial parts without flowers for certain plants (Table 1). Infusion in water is the most common method of preparation for the recorded medicinal plants in the region, although preparation methods depend on the purpose of the plants' use. The water infusions are used mostly to heal internal inflammations of the digestive, respiratory, and urinary-reproductive systems. The use of plants for their hypotensive effect and the regulation of blood pressure is the next most popular employment of these plants. Some participants also eat the sour branches or leaves of medicinal plants (Berberis, Rumex, etc.) to lower their blood pressure. The spirit infusions and home-made vodkas have uses which are similar to those of water infusions. Medicinal plants in Tatev and the neighboring villages are also used to heal skin inflammations, joint pain, and, in some cases, to treat headaches (possibly associated abnormal blood pressure), and intestinal worms (Table 1).

Our research participants' knowledge of medicinal plants and folk herbal medicine was acquired from three primary sources: 1) Their own family and community, 2) People from other communities (relatives from other regions, guests/visitors, tourists, etc., and 3) "Official" sources (books, the Internet, TV, local officials, etc.).

Information learned from the senior members of their family and community is considered traditional by our research participants. There are several pieces 
Table 1 Major medicinal and aromatic plants gathered and used by the population of Tatev and neighboring villages (Syunik region, Armenia).

\begin{tabular}{|c|c|c|c|c|}
\hline Plants' local names & Scientific names & Parts used & Preparation & Remedies/Uses \\
\hline tyakhtse / injwhuðn & $\begin{array}{l}\text { Mentha spp. (Lamiaceae): } \\
\text { M. longifolia (L.) Hudson }\end{array}$ & aerial parts & water infusion & $\begin{array}{l}\text { anti-inflammatory: } \\
\text { digestive, respiratory; } \\
\text { antihypertensive, "good for } \\
\text { heart" }\end{array}$ \\
\hline \multirow[t]{2}{*}{ khorne / hunnlu } & $\begin{array}{l}\text { Thymus spp. (Lamiaceae): } \\
\text { Th. eriophorus Ronn. } \\
\text { Th. rariflorus K. Koch }\end{array}$ & aerial parts & water infusion & $\begin{array}{l}\text { anti-inflammatory: } \\
\text { digestive, respiratory; anti- } \\
\text { hypertensive }\end{array}$ \\
\hline & $\begin{array}{l}\text { Ziziphora spp. (Lamiaceae): } \\
\text { Z. clinopodioides Lam. } \\
\text { Z. serpyllacea Bieb. }\end{array}$ & & & \\
\hline $\begin{array}{l}\text { meshehamouk / } \\
\text { Un2nhuuUnıl4 }\end{array}$ & $\begin{array}{l}\text { Hypericum spp. } \\
\text { (Hypericaceae): } \\
\text { H. perforatum L. } \\
\text { H. linarioides Bosse }\end{array}$ & $\begin{array}{l}\text { aerial parts } \\
\text { with flowers }\end{array}$ & water infusion & $\begin{array}{l}\text { anti-inflammatory: } \\
\text { digestive, respiratory, } \\
\text { urinary-reproductive }\end{array}$ \\
\hline \multirow[t]{3}{*}{$\begin{array}{l}\text { eghenthapa / } \\
\text { nnnupurumu }\end{array}$} & $\begin{array}{l}\text { Cephalaria spp. } \\
\text { (Dipsacaceae): }\end{array}$ & flowers & water infusion & $\begin{array}{l}\text { anti-inflammatory: } \\
\text { respiratory }\end{array}$ \\
\hline & C. gigantea (Ledeb.) Bobrov & & & \\
\hline & $\begin{array}{l}\text { Knautia montana (Bieb.) DC } \\
\text { (Dipsacaceae) }\end{array}$ & & & \\
\hline 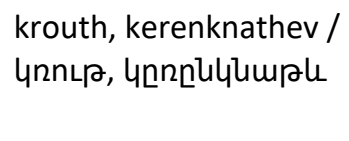 & $\begin{array}{l}\text { Arctium spp. (Asteraceae): } \\
\text { A. palladinii (Marc.) Grossh. } \\
\text { A. lappa L. }\end{array}$ & leaves & $\begin{array}{l}\text { no preparation, } \\
\text { direct application }\end{array}$ & to treat joint pain \\
\hline \multirow[t]{4}{*}{$\begin{array}{l}\text { tekhtekorne / } \\
\text { unnhuunnlnnlun }\end{array}$} & $\begin{array}{l}\text { Plantago spp. } \\
\text { (Plantaginaceae): }\end{array}$ & leaves & $\begin{array}{l}\text { no preparation, } \\
\text { direct application }\end{array}$ & anti-inflammatory: skin \\
\hline & P. major L. & & water infusion & $\begin{array}{l}\text { anti-inflammatory: } \\
\text { digestive, urinary- } \\
\text { reproductive }\end{array}$ \\
\hline & $\begin{array}{l}\text { Tussilago farfara } \mathrm{L} . \\
\text { (Asteraceae) }\end{array}$ & & $\begin{array}{l}\text { no preparation, } \\
\text { direct application }\end{array}$ & anti-inflammatory: skin \\
\hline & & & water infusion & $\begin{array}{l}\text { anti-inflammatory: } \\
\text { respiratory }\end{array}$ \\
\hline \multirow[t]{3}{*}{ 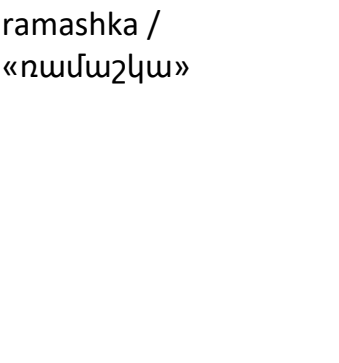 } & $\begin{array}{l}\text { Leucanthemum spp. } \\
\text { (Asteraceae): } \\
\text { L. vulgare L. }\end{array}$ & $\begin{array}{l}\text { aerial parts } \\
\text { with flowers }\end{array}$ & water infusion & $\begin{array}{l}\text { anti-inflammatory: } \\
\text { digestive }\end{array}$ \\
\hline & $\begin{array}{l}\text { Anthemis spp. (Asteraceae): } \\
\text { A. triumfettii (L.) All. }\end{array}$ & & & \\
\hline & $\begin{array}{l}\text { Tanacetum spp. } \\
\text { (Asteraceae): T. parthenium } \\
\text { (L.) Sch. Bip. }\end{array}$ & & & \\
\hline $\begin{array}{l}\text { tsyeuthoran / } \\
\text { gృnıpnnul }\end{array}$ & $\begin{array}{l}\text { Satureja hortensis L. } \\
\text { (Lamiaceae) }\end{array}$ & aerial parts & water infusion & against intestinal worms \\
\hline
\end{tabular}

(continued on next page) 
(continued from previous page)

Table 1 Major medicinal and aromatic plants gathered and used by the population of Tatev and neighboring villages (Syunik region, Armenia).

\begin{tabular}{|c|c|c|c|c|}
\hline Plants' local names & Scientific names & Parts used & Preparation & Remedies/Uses \\
\hline chaman / zuưul & $\begin{array}{l}\text { Carum spp. (Apiaceae): } \\
\text { C. carvi L. }\end{array}$ & fruits & water infusion & $\begin{array}{l}\text { anti-inflammatory: } \\
\text { digestive }\end{array}$ \\
\hline zira / qhnu & $\begin{array}{l}\text { Laser trilobum (L.) Borkh. } \\
\text { (Apiaceae) }\end{array}$ & fruits & water infusion & $\begin{array}{l}\text { "good for heart", to } \\
\text { regulate blood pressure }\end{array}$ \\
\hline $\begin{array}{l}\text { khendzoratsaghik / } \\
\text { hulănnudounhly }\end{array}$ & $\begin{array}{l}\text { Trifolium pratense } \mathrm{L} . \\
\text { (Fabaceae) }\end{array}$ & flowers & water infusion & "good for heart" \\
\hline $\begin{array}{l}\text { khenkatsaghik, se- } \\
\text { vakhot / hulumounhl, } \\
\text { ulumpunun }\end{array}$ & $\begin{array}{l}\text { Origanum vulgare L. } \\
\text { (Lamiaceae) }\end{array}$ & $\begin{array}{l}\text { aerial parts } \\
\text { with flowers }\end{array}$ & water infusion & $\begin{array}{l}\text { anti-inflammatory: } \\
\text { digestive; to regulate blood } \\
\text { pressure }\end{array}$ \\
\hline $\begin{array}{l}\text { mayramakhot / } \\
\text { Uujpuuvuhunun }\end{array}$ & $\begin{array}{l}\text { Teucrium polium L. } \\
\text { (Lamiaceae) }\end{array}$ & $\begin{array}{l}\text { aerial parts } \\
\text { with flowers }\end{array}$ & water infusion & anti-inflammatory \\
\hline ankhos / mluhunu & $\begin{array}{l}\text { Bryonia spp. } \\
\text { (Cucurbitaceae): } \\
\text { B. dioica Jacq. }\end{array}$ & $\begin{array}{l}\text { roots } \\
\text { young } \\
\text { sprouts with } \\
\text { leaves }\end{array}$ & $\begin{array}{l}\text { spirit infusion } \\
\text { water infusion }\end{array}$ & $\begin{array}{l}\text { "good for heart" } \\
\text { anti-inflammatory: } \\
\text { digestive; to treat joint pain } \\
\text { anti-inflammatory: } \\
\text { digestive }\end{array}$ \\
\hline masour / Uuunın & $\begin{array}{l}\text { Rosa spp. (Rosaceae): } \\
\text { R. canina L. }\end{array}$ & fruits & water infusion & $\begin{array}{l}\text { anti-inflammatory: } \\
\text { respiratory }\end{array}$ \\
\hline $\begin{array}{l}\text { khendeghne / } \\
\text { hunluntinlun, pangi / } \\
\text { utiluqh }\end{array}$ & $\begin{array}{l}\text { Sambucus spp. (Adoxaceae): } \\
\text { S. nigra L., } \\
\text { S. ebulus L. }\end{array}$ & fruits & home-made vodka & $\begin{array}{l}\text { anti-inflammatory: } \\
\text { digestive, respiratory; to } \\
\text { regulate blood pressure, to } \\
\text { treat headaches }\end{array}$ \\
\hline $\begin{array}{l}\text { sezne / unqun, } \\
\text { halouch / huını6 }\end{array}$ & $\begin{array}{l}\text { Crataegus spp. (Rosaceae): } \\
\text { C. rhipidophylla Gand. }\end{array}$ & $\begin{array}{l}\text { branches } \\
\text { with leaves } \\
\text { and flowers, } \\
\text { fruits }\end{array}$ & $\begin{array}{l}\text { water infusion, } \\
\text { eating without } \\
\text { preparation (fruits) }\end{array}$ & $\begin{array}{l}\text { "good for heart", } \\
\text { antihypertensive, to treat } \\
\text { headaches }\end{array}$ \\
\hline $\begin{array}{l}\text { ketsoukhour / } \\
\text { unðnடhunın }\end{array}$ & $\begin{array}{l}\text { Berberis spp. } \\
\text { (Berberidaceae): } \\
\text { B. vulgaris L. (=B. orientalis } \\
\text { C. K. Schneid.), } \\
\text { B. integerrima Bunge }\end{array}$ & $\begin{array}{l}\text { leaves, } \\
\text { young } \\
\text { sprouts, } \\
\text { fruits }\end{array}$ & $\begin{array}{l}\text { water infusion, } \\
\text { eating without } \\
\text { preparation }\end{array}$ & antihypertensive \\
\hline tandz / unuluă & $\begin{array}{l}\text { Pyrus spp. (Rosaceae): } \\
\text { P. caucasica Fed. }\end{array}$ & fruits & $\begin{array}{l}\text { water infusion, } \\
\text { home-made vodka, } \\
\text { eating without } \\
\text { preparation }\end{array}$ & $\begin{array}{l}\text { anti-inflammatory: } \\
\text { digestive (to treat diarrhea) }\end{array}$ \\
\hline
\end{tabular}



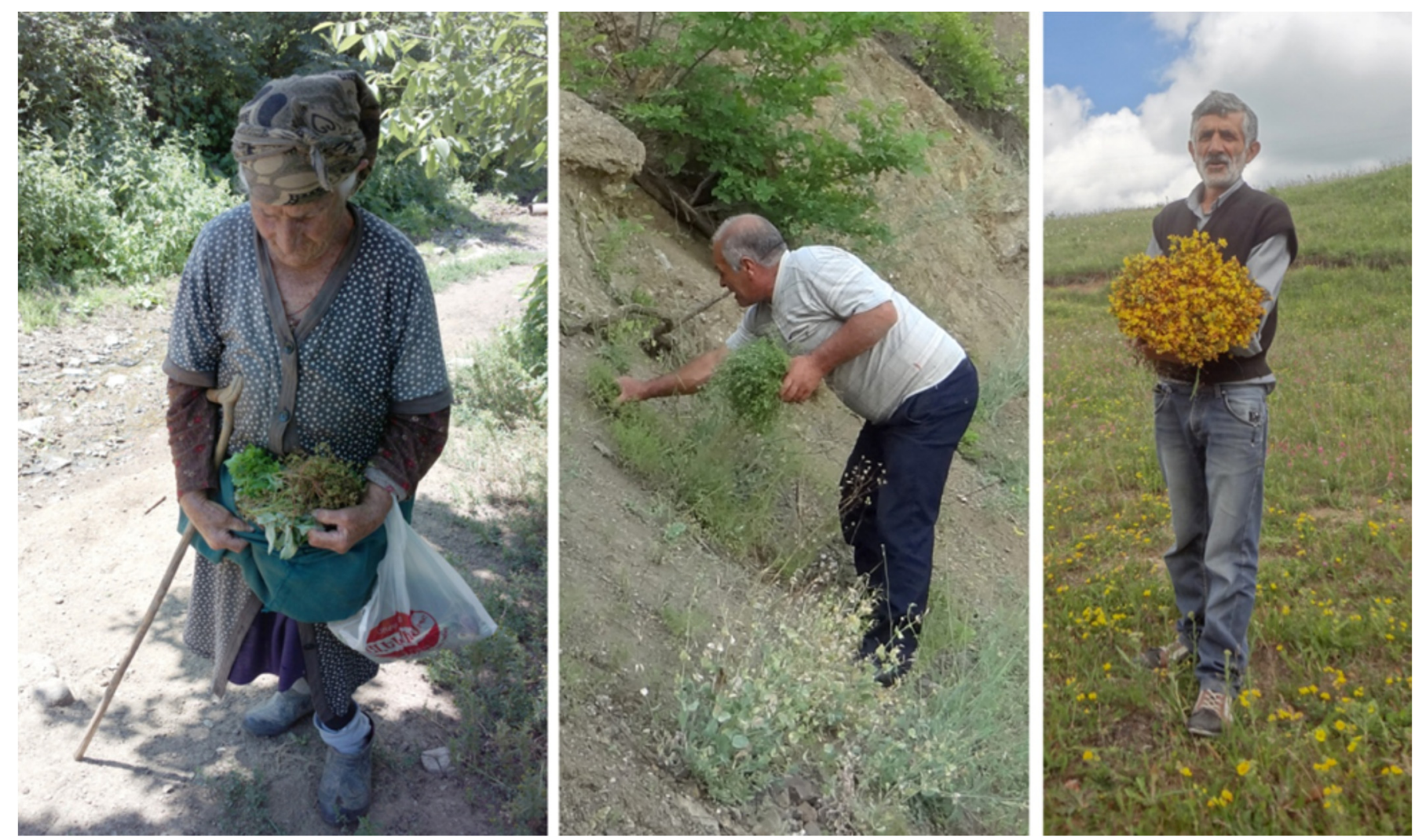

Figure 5 Wild plant harvesting activities of the locals (June 2017, Armenia). The woman (v. Tandzatap) gathered wild "tyakhtse" (Mentha longifolia) and "chaman" (Carum carvi) from her yard. The man in the center image (v. Tatev) was collecting "tseuthoran" (Satureja hortensis) from a dry slope along the road from Devil's Bridge to Tatev village. The man in the right image (v. Tatev) gathered "meshehamouk" (Hypericum perforatum) from the meadows between Tatev and Tandzatap villages.

of evidence to suggest that the medicinal and aromatic plants in Table 1 have been used by the locals of this community for at least the last few centuries. These include the presence and popularity of the local names, which is often different from the books; the widespread, persistent, and diverse folk medicinal practices; the narratives about or involving these plants, which have seen continuous use for at least the twentieth and twenty-first centuries; and research participants' memories from childhood, including the stories told and retold by their grandparents and elders.

Traditional knowledge of folk herbal medicine is usually backed up by the experiences of research participants and their family members. However, the knowledge a research participant possesses does not always originate from their own family practices. In some cases, a medicinal plant traditionally used in the community is not very popular (such as Bryonia dioica, the roots of which are difficult to dig up). In other cases, the preparation method is somewhat complicated and not available to everyone, as with a spirit made of Sambucus ebulus. Due to these obstacles and also due to differences in family customs, some of the research participants and their family members never used certain plants, never prepared certain remedies, used the remedy in another way, or used it for another purpose. However, they knew about the plants' remedies, preparations, and uses, and attested that they are traditionally used plants in the community even if they themselves do not prepare and use them. In these cases, our research participants gave us information not only about the ethnomedicinal knowledge of their families, but also about the medicinal plants and phytomedicinal practices of their community in general. Thus, they served as intermediaries between us and other members of their community and expanded the coverage of our knowledge. These research participants, who are bearers of community level 
knowledge, often transmit that knowledge to younger generations.

As our research participants attested, they learned about medicinal plants and folk medicinal practices from their parents, grandparents or other more experienced and usually older relatives and fellow villagers when they participated in or witnessed the gathering of plants. Parents, grandparents, and other experienced relatives deliberately teach children and young members of the community during this activity. Participants also witnessed plant conservation during winter storage or transportation, preparation, and use. Otherwise, children and young members of the community learned plant knowledge from the discussions and knowledge exchanged within the community or heard the corresponding stories through oral lore. Our research participants for the most part trust their traditional folk medicinal knowledge and believe in the medicinal efficacy of the plants they use, although sometimes they say the contrary when interacting with "officials".

The attitude toward the information our research participants receive from outside of their community depends on the source. They remembered the plants and herbal remedies about which people from other communities told them, but there was a certain skepticism about the efficacy and safety of these plants and their preparation ("I heard it from X but I am not sure / I do not know does it help or not.").

Information from books is considered the most trustworthy. The attitude toward information from the internet and TV is equivocal and mostly depends on the educational level of the research participant; those with a higher educational level, usually also younger, trust TV and the internet less, while elderly people trust all kinds of "official" sources. Nowadays, members of the Tatev community learn about "new" (non-traditional) medicinal plants and phytomedicinal practices from books, TV, the internet, and other "official" sources. In this way, some novelties may sneak into the folk phytomedicinal practices of the community and these may be considered traditional if the source of knowledge becomes forgotten. We suspect that Teucrium polium L. (Lamiaceae), which is used as an anti-inflammatory remedy for the digestive system and has already become popular in this community, is such a case, as some of the families we worked with knew this plant but they did not remember it ever being used in their family or mentioned by their parents and grandparents. Other wild plants little known or practically unknown to the members of the Tatev community include Acbillea biebersteinii Afan., $A$. millefolium L., Artemisia absinthium L., Cichorium intybus L. (Asteraceae), Pinus kochiana Klotzsch ex K.Koch (Pinaceae), Salvia verticillata L. (Lamiaceae), Scrophularia sp. (Scrophulariaceae), Syringa vulgaris L. (Oleaceae), and Tilia cordata Mill. (Tiliaceae). All medicinal and aromatic plants traditionally used in the community (Table 1), as well as the above-mentioned (presumably novel) plants are traded in the Tatev market.

When questioning the traders of Tatev market about medicinal plants, they almost always used official names of the plants and referred to books as sources of knowledge. In fact, all traders in the market have some illustrated popular handbook of medicinal plants on hand (such as Hovhannisyan 2005 and Ghazanchyan 2013; Figure 4). Suspecting that the traders' knowledge might be derived from books and possibly that the traded plants were not traditionally used ones, we directly asked them: "Did you know about these medicinal plants before?" or "Were the locals using these medicinal plants in the past also?" Although we referenced and showed the most popular medicinal plants in Tatev while were asking the abovementioned questions, the answers were equivocal and confusing. Some of the traders told us that they only recently learned about these plants from books and that they did not know about the useful features of those plants before. Others attested that most of the plants for sale are popular for the region and are traditionally used as medicinal and aromatic plants. One of the traders, a woman, said: "We know these [medicinal and aromatic] plants very well and use them. Our grandparents used them, but we prefer to learn about these plants from books." Our interviews and observations showed that the traders are carriers of traditional ethnobotanical knowledge, but they also enriched their knowledge about traditionally used medicinal and aromatic plants by using books. The traders learned about the above-mentioned "new" medicinal plants from books, from the internet, and from herbalists.

We observed a similar situation in the villages as well; when we traveled to different locales and asked people to tell us about the medicinal plants they use, the locals often suggested that we read a corresponding book instead or tried to direct us to somebody with a higher education (teacher, agronomist, doctor, etc.), saying that he/she has 
higher education ("he has read") and will know about it and/or he/she may have books. When we ask them, "Why don't you want to tell us?" the answer was, "I have not learned/read it, I might not know about it." Locals often told us that they are "illiterate" meaning that they have not officially learned or read about the particular question. In one case, an interviewed elderly person wondered: "You are the man with higher education. You should tell me about them [medicinal plants]. Instead, you come and ask me?" The investigations show that these regular people with primary or secondary school education, despite their humble, yet sincere, opinion about themselves, possess knowledge about the questions we asked. Meanwhile, when we talked to someone with higher education and an official position, such as an agronomist or a teacher, they repeated information taken from books and suggested the books they learned from.

We would like to highlight the fact that while introducing the plants, our research participants, who included traders, villagers with higher education, and many of the regular villagers, often used the official names of each plant and often gave preference to the Russian names over the Armenian ones, although all of them knew the local names.

\section{Discussion}

Why do some of the traders believe that they did not know these plants before? And why do many of the locals belittle their traditional ethnobotanical knowledge, transmitted through oral lore or direct learning, while overvaluing the books and fellow villagers with higher education or administrative positions? We believe that the reason is the particular attitude the locals of the community have toward written sources. This is especially true in the attitudes toward printed sources and the people who manage these sources, as they are able to understand and interpret the official language and terms. These terms are not familiar to most of the residents of the villages, despite the population being overwhelmingly literate. Here we observe a phenomenon where locals consider only that information which they learn through reading written/printed sources to be "true knowledge". In general, information presented in professional and popular-professional books published in the Soviet period was systematic, well organized, rich, and precise.

Books and other printed sources had richer vocabulary and were accompanied by scientific terms and data, and they also lacked grammatical mistakes as all steps of publication were thoroughly controlled. This is because the texts and speech were composed by educated people who were representatives of the Soviet authorities. These experts helped to make the typed texts more respectable to the general public. Although printed sources are no longer controlled in the aftermath of the collapse of the Soviet Union and contemporary books can be published and distributed regardless of their quality, the generation of the Soviet period still holds reverence for books. Soviet printed propaganda, which highlighted the importance of education and official medicine while criticizing folk medicine, has contributed to the prestige of books and other official sources. While we are confident in this observation, we note that no members of the Tatev community specifically mentioned Soviet influence as a factor for this trust in written sources.

We recorded a similar phenomenon in the trade at the market of Tatev. Sellers stated during our interviews that their buyers are primarily Armenians from Armenia and abroad as well as Russians who buy medicinal plants and transport them to Russia and other countries in which they live. Meanwhile, foreigners, particularly from the EU, USA, and Canada, are afraid that they may have problems with customs and hesitate to buy herbs. Our observations in the market and our analysis of this difference in buyers' attitudes showed that the buyers' knowledge of medicinal and aromatic plants has a major decisive role in their choices (this conclusion is confirmed by the traders). Armenians seem to know the traded herbs better than the foreigners. Furthermore, they comprise the majority of herb buyers, as reported by the traders. In other words, people buy what they know and avoid unknown products. The traders of the market at Tatev are already aware of this phenomenon and they have found solutions for the problem. One solution is the use of official names of the traded plants, with the expectation that this will make them more recognizable. The traders use official Russian, Armenian, and English names of herbs during their spoken interactions with buyers. Additionally, the boxes and packs with herbs have stickers with official names of the plant in Russian, Armenian, or English. Another solution is the use of popular illustrated or pop-science books about medicinal plants. Almost all of the traders have such books on hand or borrow one from fellow traders. When a seller sees that the buyers have doubts about a particular plant and its use or that the buyer is not 
satisfied with the verbal information the seller provides (such as the names and potential uses), the seller will take the book out, find the corresponding plant and show or read out the pertinent articles to lend authority to their claims and convince the customers to buy (Figure 4). Information from books is respected as official and definitive and is considered more trustworthy by both traders and buyers (the books' validity is rarely doubted), so the traders of the market in Tatev try to inform potential customers by using corresponding books on medicinal plants to sell their own goods. In order to increase the trust of buyers towards the traded herbs, the traders also state that the same plants (e.g., Achillea, Artemisia, Cichorium, etc.) are sold in pharmacies as well (this also was controlled by the Soviet government). The traders of the market also give free samples to potential clients to test in order to introduce the goods (herbs, food, drinks) they have for sale and to encourage the visitors to buy their products.

Using the strategy of implementing plants' official names and introducing information from books appears to work better with Russian tourists as opposed to foreigners of other nationalities. However, it seems that supplying buyers with information from books is much more effective when traders deal with Armenians.

\section{Conclusions}

We hypothesize that Soviet propaganda against folk medicine is the reason that locals in the Tatev community belittle their own traditional ethnomedicinal and ethnobotanical knowledge and overvalue the information presented in books or provided by people with higher education and by administrative officials. Because official knowledge, education, and propaganda in the Soviet period were controlled and distributed primarily via printed media since the earliest stages of the Soviet period, regular people began to consider books and other printed sources to be more prestigious than their traditional knowledge. Nowadays the same "official" sources contribute to the development of folk phytomedicine and the creation of corresponding "new traditions". Thus, after several decades, Soviet propaganda, which was fighting against folk medicine using official sources, nowadays indirectly contributes to the enrichment and preservation of phytomedicinal knowledge and traditions.

\section{Notes}

${ }^{1}$ Corresponding materials may be found in all early Soviet period (e.g., 1920s) popular newspapers and journals related to medicine, health, household, and other spheres (e.g., Healthy Life, Healthy Lifestyle, Health Care Fronts, Female worker of Armenia, etc.).

2 The official website of the administration of the Syunik region with specific information about the Tatev Community. http://syunik.mtad.am/aboutcommunities/991/ (in Armenian)

3'TaTever: wings of Tatev. Facts and Advice. http://www.tatever.am/en/wings-facts-and-advice

${ }^{4}$ There is a counter-shop run by an owner from Yerevan that re-sells products bought in Yerevan or elsewhere (they advertise their products as being locally produced).

\section{Acknowledgments}

We wish to thank all our research participants for their contribution to the current study and particularly Samvel Parsyan from v. Tatev for his contribution and assistance with the organization of our field-work. Salpi Bocchieriyan copyedited the paper before the submission.

\section{Declarations}

Permissions: We informed our research participants that we are going to publish the results of our research including the information we got from them and the pictures, which we took with their permission. In many cases, our research participants especially asked to be photographed for further publication (e.g., the photos of those we submit as a part of our paper).

Sources of funding: None declared.

Conflicts of Interest: None declared.

\section{References Cited}

Allayarov, Kh. A. 1993. The History of Traditional Medicine in Central Asia. Unpublished Doctoral Dissertation, Scientific Research Center "Medical Museum" of the Russian Medical Academy, Moscow (in Russian).

Ayvazyan, Ye. 1927. The Doctor in Our Village.

Female Worker of Armenia 11:28 (in Armenian).

Bashkuev, V. Yu. 2017. The Confrontation between Soviet and Tibetan Medicine in the Late 1920sEarly 1930s. Power 2:157-162 (in Russian).

Blium, A. V., and D. Farina. 1998. Forbidden Topics: Early Soviet Censorship Directives. Book History 1:268-282. 
Boldyrev, R. 2017. Propaganda of Health and Hygiene in the USSR [web page]. Available at: http:// infosplanet.info/plakaty-i-listovki/propagandazdorovya-i-gigieny-v-sssr/. Accessed on February 1, 2019 (in Russian).

Eaton, K. B. 2004. Daily Life in the Soviet Union. Greenwood Press, Westport, Connecticut, London.

Ghazanchyan, M. 2013. Medicinal Plants for Everyone. Prescriptions and Remedies. Luys, Yerevan (in Armenian).

Grigorov, N. 1891. Village Tatev. Collection of Materials for Describing the Localities and Tribes of the Caucasus 13:59-125 (in Russian).

Harutyunyan, M. 1927. “Liberating” Midwife. Female Worker of Armenia 9:17 (in Armenian).

Hovhannisyan, J. 2005. Green Box of Medicine. Zangak, Yerevan (in Armenian).

International Society of Ethnobiology. 2006. International Society of Ethnobiology Code of Ethics (with 2008 additions) [web page]. Available at: http:// ethnobiology.net/code-of-ethics/. Accessed on February 1, 2019.

Khudabashian I. 1917a. Criminal Abortion. Healtby Life 1:4-6 (in Armenian).

Khudabashian I. 1917b. Preventive Means against Birth Fever. Healthy Life 4:19-22 (in Armenian).

Knaus, W. A., and N. A. Petroff. 1982. Inside Russian Medicine: An American Doctor's First-Hand Report. Everest House Publishers, New York, NY.

Lisitsyan, S. 1969. Armenians of Zangezur. AS Arm. SSR, Yerevan (in Armenian).
Malkhasyan, B. J. 1929. Trachoma and the Fight Against It. Healtby Lifestyle 1:16-18 (in Armenian).

Markwick, R. D. 2013. Censorship and Fear: Historical Research in the Soviet Union. Groniek 46:371385.

Medynskiy, E. N. 1952. Public Education in the USSR. Academy of Pedagogical Sciences of the RSFSR, Moscow (in Russian).

Mirakyan I. 1930. Doctor's Comments. Healtby Life 23:43-44 (in Armenian).

Mikhlin, V. M., and V. A. Kiryak. 1985. Non-Classical Healing: The Past and the Present. "Stiynets", Chisinau (in Russian).

Ohanyan. 1917. The Oculist's Discussions. The Eyes of the Elderly People. Healthy Life 6-7:9-13 (in Armenian).

Phillips, S. D. 2004. Waxing Like the Moon: Women Folk Healers in Rural Western Ukraine. Folklorica 9:13-45.

Plamper, J. 2001. Abolishing Ambiguity, Soviet Censorship Practices in the 1930s. The Russian Review 60:526-544.

Q.O. 1917. Mailbox. Healthy Life 6-7:30 (in Armenian).

Takhtajyan, A. L. ed. 1954-2010. Flora of Armenia. Vol. 1-11 (In Russian).

Venclov, T. 1978. USSR: Stages of Censorship. Index on Censorship 7:61-62. 